\title{
Temporal distribution of size and maturity stages of the chaetognath Sagitta setosa in the western English Channel
}

\author{
Vidar Øresland \\ Department of Zoology, University of Stockholm, S-106 91 Stockholm, Sweden
}

\begin{abstract}
Oblique plankton hauls were taken 1 to 3 times a month during 1982 and 1983 off Plymouth, England. Sagitta setosa occurred in low numbers during spring and early summer but increased in late summer and autumn. This seasonal increase can be attributed to reproduction and in part to immigration from outside the sampling area as a result of advection. $S$. setosa in the western Channel was much larger during winter and spring compared to $S$. setosa in the northern Kattegat, an area with much lower temperature. This indicates that temperature may be an important growthregulating factor (direct and/or indirect) for this species. S. setosa had a 1 yr life cycle. Breeding occurred over a long period, from June to December, with a peak from July to early October. In the 1930 's F. S. Russell proposed 6 generations a year for $S$. setosa off Plymouth. Considering the large mesh size of the plankton net, and the occurrence of different populations due to advection, his results can be reinterpreted as agreeing with the new data.
\end{abstract}

\section{INTRODUCTION}

The chaetognath Sagitta setosa J. Müller is a predator on zooplankton and is regarded as an indicator species of indigenous North Sea water and Channel water (Russell 1935, 1939). This species, as well as $S$. elegans Verrill, is of special interest when studying large scale community changes in the English Channel, called 'The Russell Cycle' (see Cushing \& Dickson 1976, Southward 1980, 1984, Cushing 1982). To understand such changes, detailed information about the breeding behaviour and the life cycle of the involved species is important.

Earlier studies on the life cycle of Sagitta setosa have shown contradictory results (Øresland 1983). The present investigation was made to check the results reported by Russell (1932), who found 6 generations per year of $S$. setosa off Plymouth. In the present paper the size and maturity stage distribution of $S$. setosa off Plymouth during 1982 and 1983 is presented, and the life cycle of the species is discussed.

\section{HYDROGRAPHY}

The current system in the English Channel is complex. Inflowing water at the western and eastern en- trances of the Channel may show great seasonal and annual variations in strength and direction. The exchange of water between the western and eastern Channel is much less than the flow within the western Channel (Dietrich 1950). For the western Channel Southward (1962) related 'northwestern' and 'southwestern' plankton species to seasonal flows of water of different origin and direction. Eddies, tides, and other hydrographical features as well as wind stress have a great impact on the hydrographical situation in the Channel. A comprehensive presentation of the hydrography of the Channel is given by Pingree (1980).

Hydrographical data were collected monthly at the routine hydrographical station E1 (depth $70 \mathrm{~m}$ ), which is close to the routine plankton station L5 (depth $65 \mathrm{~m}$ ), but more strongly stratified (Fig. 1). The surface and bottom salinity values show small changes around $35 \%$. No halocline is thus present. The surface temperature normally ranges from 9 to $18^{\circ} \mathrm{C}$ and the bottom temperature from 9 to $14{ }^{\circ} \mathrm{C}$. A thermocline $(3$ to $6 \mathrm{C}^{\circ}$ discontinuity) is normally present from June to September at 15 to $20 \mathrm{~m}$ depth. Temperature may affect the number of generations of Sagitta setosa per year. It is therefore of interest to compare temperature and the number of generations found in the warmest and the coldest areas where the species occurs more or less throughout the year, viz. the western Channel and 


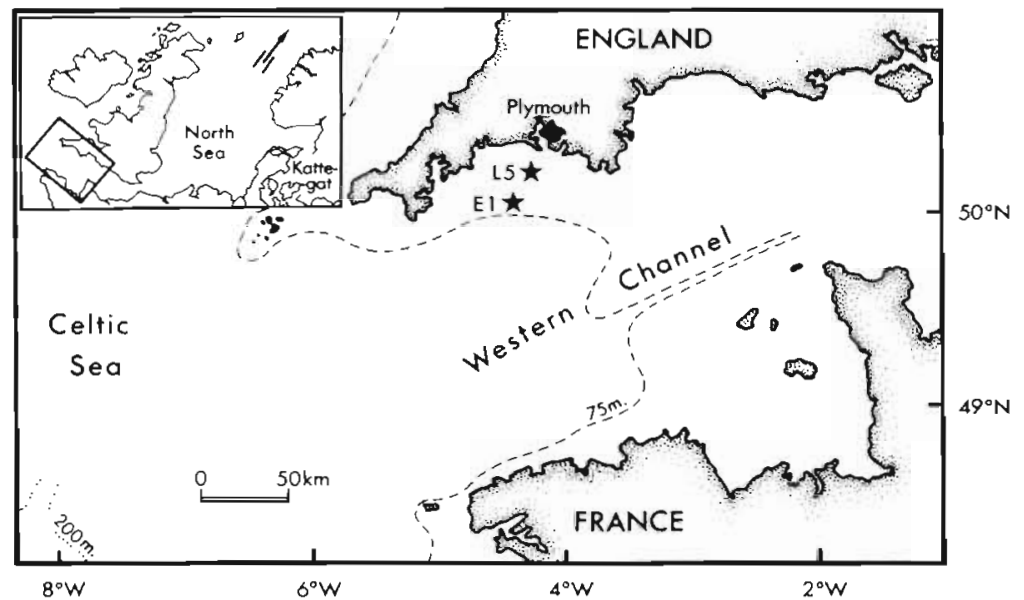

Fig. 1. Plankton Station L5 and hydrographical Station E1 in the western English Channel

the northern Kattegat (isolated Mediterranean populations are not considered). Fig. 2 compares surface layer temperatures in these 2 areas.

\section{MATERIALS AND METHODS}

The zooplankton samples for this study were taken at Station L5, $3 \mathrm{~km}$ west of Eddystone Lighthouse, off Plymouth (Fig. 1). The samples were intended to be taken at weekly intervals. Owing to weather and other problems the sampling frequency in 1982-83 was from 1 to 3 times a month. A $3 \mathrm{~m}$ long terylene net was used, fastened to a square frame of $0.9 \times 0.9 \mathrm{~m}$, instead of a $1 \mathrm{~m}$ ring (Southward 1970). The mesh size of the net was $700 \mu \mathrm{m}$ and the bucket at the end of the net was perforated by $300 \mu \mathrm{m}$ holes. The net was equipped with a 'Scripps' $20 \mathrm{~kg}$ depressor. Obljque hauls were

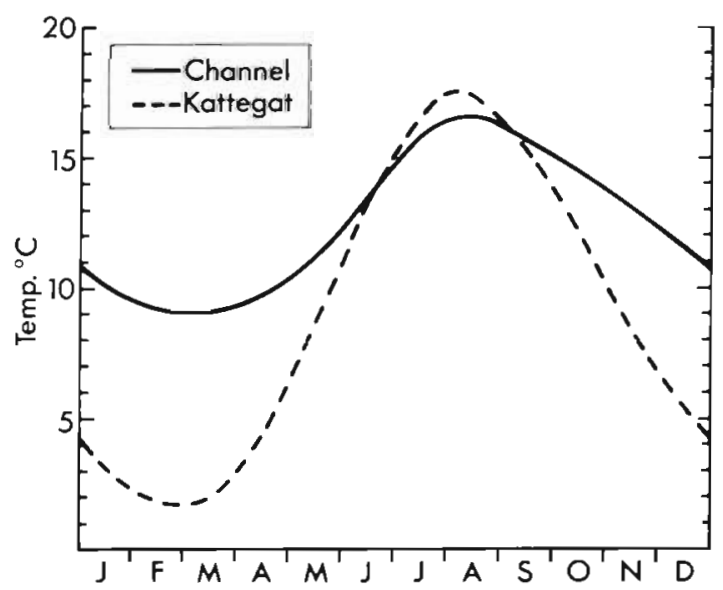

Fig. 2. Temperatures at Station E1 off Plymouth (data supplied by the Marine Biological Association, Plymouth) and at the lightship Läsö Trindel in the northern Kattegat (data from Fish. Bd Sweden, Rep. Ser. Hydrography). The temperature curves are drawn through monthly mean values, from 1931 to 1960. Measurements were made (monthly at E1, daily at Läsö Trindel) at 0,5 and $10 \mathrm{~m}$ made for about 20 min from the surface down to 5 to $10 \mathrm{~m}$ above the bottom and up to the surface again. The performance of the net was checked from time to time with a depth recorder and flowmeter (Southward 1970). The speed of the net was approximately $1 \mathrm{~m} \mathrm{~s}^{-1}$ and the samples were taken in daylight, between 0640 and $1440 \mathrm{~h}$. All samples were preserved in $4 \%$ formaldehyde in seawater, buffered with borax. Samples and subsamples (taken with a dipping beaker) were provided by Dr. Alan J. Southward, Marine Biological Association, Plymouth.

The chaetognaths were sorted out and placed on a cover glass on millimetre graph paper, all in a glass dish with water. Species identifications were made according to Kuhl (1928), Fraser (1952) and Jakobsen (1971). Sagitta setosa and S. elegans specimens were counted. $S$. setosa was measured in $1 \mathrm{~mm}$ size intervals under a stereo microscope and the occurrence of spermatophores noted. Body length was measured from the tip of the head to the end of the tail, excluding the tail fin. Maturity stages were determined according to the development of the ovaries (Zo 1973): Stage 1, no visible ovaries; Stage 2, developing ova, some ova of different sizes, no mature ovum; Stage 3, one or more mature ova (ova with a diameter larger than one quarter of body width).

\section{RESULTS}

Sagitta elegans was the dominant chaetognath during late spring and early summer, though it was not as abundant in 1982 and 1983 as in 1974 to 1979 (A. J. Southward, pers. comm.). Between 7 July and 15 July 1983, the number of $S$. elegans dropped drastically, and the frequency of $S$. elegans decreased from 69 to $6 \%$ of total Sagitta numbers. At the same time juveniles of $S$. setosa became common.

Fig. $3 \& 4$ show the temporal size and maturity stage distribution of Sagitta setosa during 1982 and 1983. In 
winter most specimens were at Stage 2. From February towards the summer, the individuals at Stage 2 gradually became mature. At the same time it was quite clear that $S$. setosa decreased in abundance. Some samples had to be combined and some were omitted due to low numbers or absence (in May 1982) of S. setosa.

Breeding was indicated from June to December by the presence of individuals at Stage 1 and by the occurrence of spermatophores (often in low frequencies) from June to October on individuals at Stage 3 (Fig. $3 \& 4$ ). No eggs were found in the samples, due to the large mesh size used. On 29 July and 21 October 1982, as well as on 1 November and 6 December 1983, some large specimens classified as at Stage 2 seemed to have reproduced. They had broken seminal vesicles and their ovaries appeared to have lost some large ova. Individuals like these are often classified as belonging to a fourth 'spent' stage, but this was not done here due to the presence of small immature ova. These speci- mens appeared to be in good condition. No individuals of Stage 2 shorter than $9 \mathrm{~mm}$ showed these signs of an earlier breeding.

Stage 3 individuals found during late summer and autumn were in general shorter than Stage 3 individuals found during spring and early summer. The largest specimen, $16 \mathrm{~mm}$ long, was found on 20 May 1983. Individual lengths ranged: at Stage 1, between 1 and $5 \mathrm{~mm}$; at Stage 2, between 2 and $15 \mathrm{~mm}$; at Stage 3 , between 7 and $16 \mathrm{~mm}$.

\section{DISCUSSION}

The western Channel is an area where the distribution boundaries of many species are found. Both Sagitta setosa and $S$. elegans show seasonal, annual and long term changes in this area (see Southward 1962 , 1964). S. setosa is generally not found in the Celtic Sea when also absent or scarce in the western
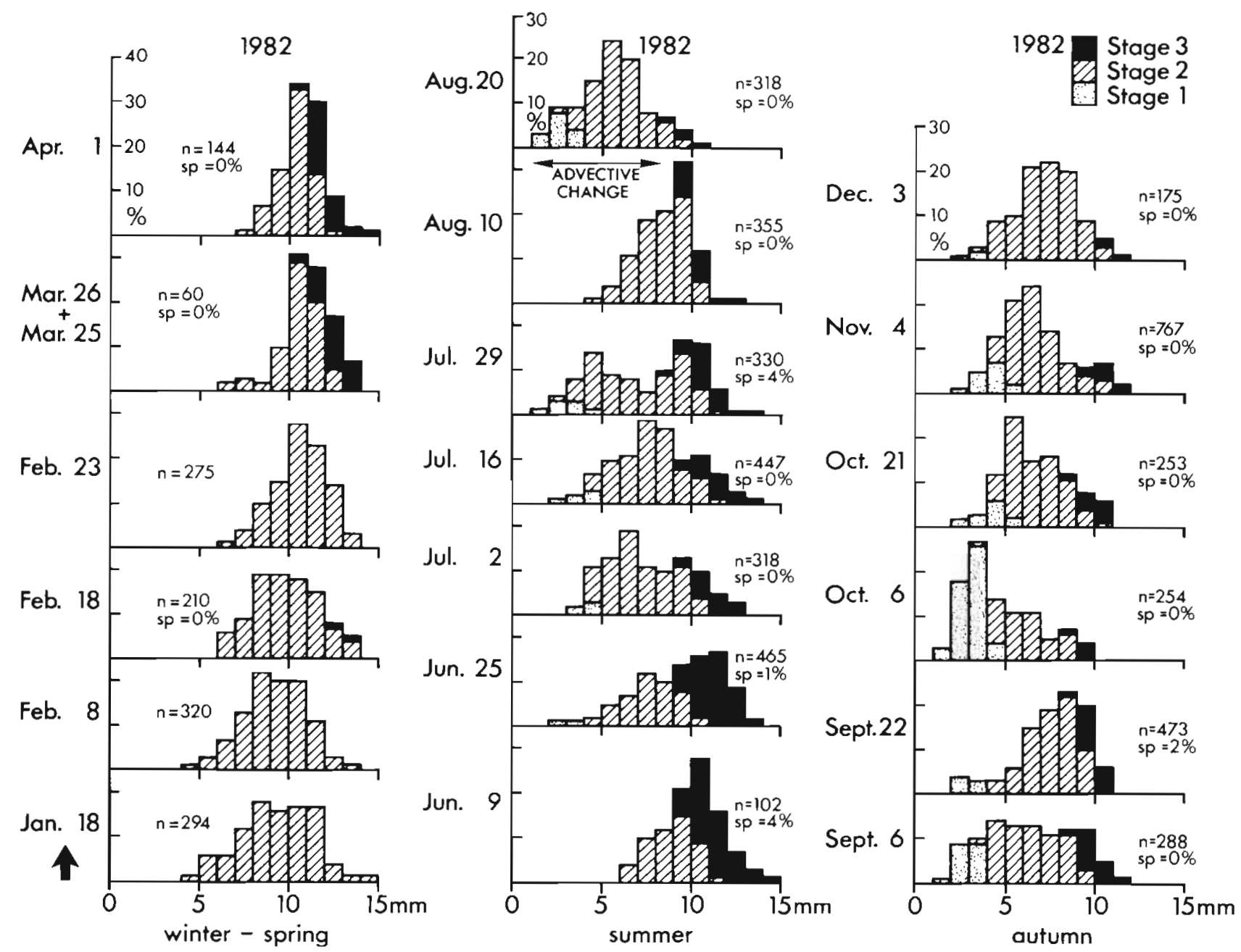

Fig. 3. Sagitta setosa. Length-frequency and maturity stage distribution at Station L.5 off Plymouth, in 1982 . $\mathrm{n}=\mathrm{number}$ of examined animals; $s p=$ frequency of individuals at Stage 3 having a spermatophore 
Channel. It is likely that the increase in numbers during late summer may be due to transport of specimens by an anticlockwise swirl approaching Plymouth (Southward 1984) which entrains with it S. setosa from the southeastern part of the western Channel as well as from east of Plymouth. S. elegans occurs throughout the year in the Celtic Sea, and a drastic decrease in the number of $S$. elegans, as in July 1983, indicates a reduction of the flow of water from the Celtic Sea.

Southward \& Barret (1983) showed that off Plymouth, Sagitta setosa may at times occur as deep as 40 to $55 \mathrm{~m}$, but is often entirely confined to the warm water above the thermocline. Russell (1931) found large specimens deeper than small ones in the same area. In the present investigation, the net was not towed very close to the bottom and large specimens may thus have been underestimated, but this is more likely to apply to $S$. elegans which shows a greater tendency for large individuals to stay deep even at night. Juveniles of both species may also have been underestimated due to the large mesh size used.
When interpreting life-span and breeding periods from size and maturity histograms, the possible immigration and mixing of populations as well as their reproductive history and behaviour should be considered. Unfortunately, no detailed data concerning the reproductive behaviour of Sagitta setosa exist. Dallot (1968) found, however, by laboratory experiments, that the species was capable of producing batches of eggs and spermatophores more than once during a life-span. This possible behaviour is regarded here as occurring within a single breeding period, until more information is available. The occurrence of 'spent' individuals at Stage 2 supports the results of Dallot (1968). No such individuals were found in the northern Kattegat (Oresland 1983), but they might have been overlooked.

Breeding was probably most intensive from July to early October (indicated by the frequency of small individuals). Fig. 3 \& 4 show no conclusive evidence that specimens born in the summer themselves breed during late summer or autumn the same year. The difference in size frequencies found between 10 and
1983

1983

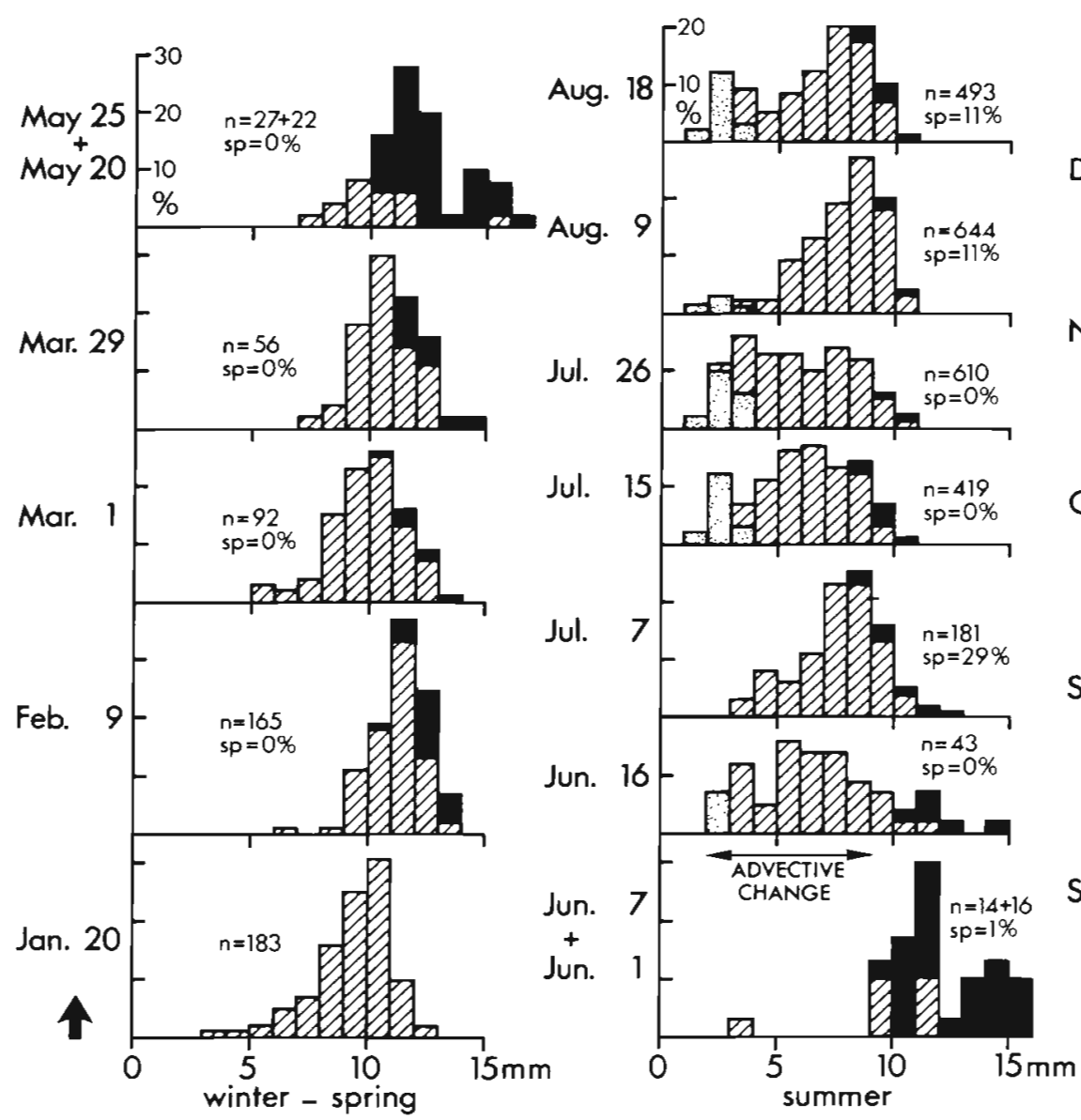

1983 Stage 3 4 Stage 2
Stage 1

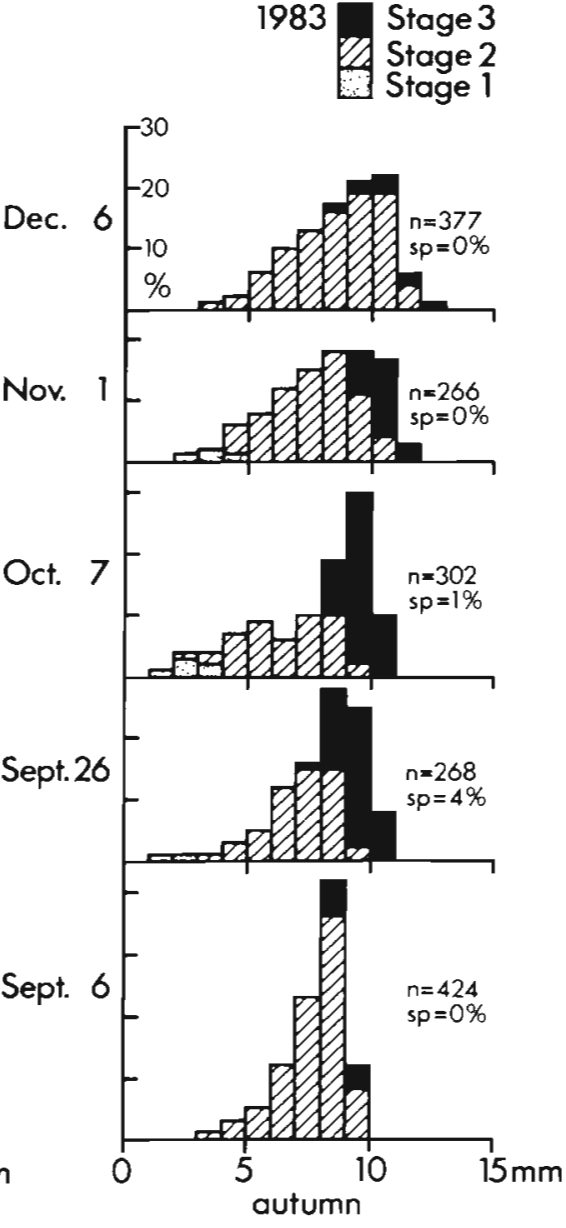

Fig. 4. Sagitta setosa. Length-frequency and maturity stage distribution at Station L5 off Plymouth, in 1983 . $\mathrm{n}=\mathrm{number}$ of examined animals; $s p=$ frequency of individuals at Stage 3 having a spermatophore 
20 August 1982, can hardly represent the appearance of a new generation, and is most probably the result of advection. Advection at this time is also indicated by a change in other plankton 'indicator' species from 'northwestern' to 'southwestern' species (A. J. Southward, pers. comm.). Advection was also evident on 16 June 1983, when Stage 2 individuals less than $9 \mathrm{~mm}$ suddenly appeared.

It is generally considered that Sagitta setosa dies soon after the breeding period, indicated by the disappearance of mature specimens (see e.g. Oresland 1983). The single breeding period per year found in the Channel would therefore indicate a 1 yr life cycle. The possibility of a shorter life cycle cannot, however, be entirely excluded, since detailed information concerning the growth rate and the reproductive behaviour is still lacking.

It was concluded by Øresland (1983) that Sagitta setosa was larger during spring and bred earlier in the southwestern North Sea compared to the Kattegat, due to better growth conditions during winter and spring. $S$. setosa in the Channel is much larger during both winter and spring and becomes mature earlier, compared to $S$. setosa in the Kattegat. This difference in size may indicate that temperature acts (directly and/ or indirectly) as a growth-regulating factor for the species in these waters. This should, however, be regarded as an open question until more information is available.

The decrease in size of individuals at Stage 3 during summer may have several causes. The largest specimens may breed earlier than the smaller ones. The smallest individuals at Stage 2 found in spring may during summer attain Stage 3 at a shorter length due to e.g. high temperature. Furthermore, there may be an immigration of small-sized individuals during summer, as mentioned above.

Russell (1932) proposed 6 generations per year of Sagitta setosa. He was, however, not sure of the existence of the first breeding period, in February, or of the number of breeding periods during summer. In Russell (1933), further doubts about the February breeding were expressed. His Plate II (Russell 1932) shows no small individuals before the end of May. During summer the frequency of individuals less than $8 \mathrm{~mm}$ is obviously underestimated, due to the large mesh size used. His Table III shows low numbers of $S$. setosa from the end of April to early August. From the middle of August to the middle of September there was an enormous increase in numbers. The data do not indicate more than 1 breeding period: from the end of May to the middle of November, with a peak during August and September. Such a conclusion is in accordance with the results of this study and Øresland $(1983,1985)$. An annual breeding cycle of this nature, if proved universal for the species in western European waters, would further underline its importance as a plankton 'indicator' of water masses and their ecosystems, and in this respect make its use more reliable than 'indicator' species known to breed more frequently.

Acknowledgements. I am most grateful to Dr, Alan J. Southward for providing the plankton samples and the temperature data. Professor Hans Ackefors and Dr. Alan J. Southward gave helpful comments on the manuscript. Figures were drawn by Bibbi Mayrhofer

\section{LITERATURE CITED}

Cushing, D. H. (1982). Climate and fisheries. Academic Press, London

Cushing, D. H., Dickson, R. R. (1976). The biological response in the sea to climatic changes. Adv. mar. Biol. 14: 1-122

Dallot, S. (1968). Observations preliminaires sur la reproduction en elevage du Chaetognathe planctonique Sagitta setosa Müller. Rapp. Comm. int. Mer. Medit. 19: 521-523

Dietrich, G. (1950). Die anomale Jahresschwankungen des Wärmeinhalts im Englischen Kanal, ihre Ursachen und Auswirkungen. Dt hydrogr. Z. 3: 184-201

Fraser, J. H. (1952). The Chaetognatha and other zooplankton of the Scottish area and their value as biological indicators of hydrographical conditions. Mar. Res. 2: 5-52

Jakobsen, T. (1971). On the biology of Sagitta elegans Verrill and Sagitta setosa J. Müller in inner Oslofjord. Norw. J. Zool. 19: 201-225

Kuhl, W. (1928). Chaetognatha. Tierwelt N.- u. Ostsee. Teil VIIb: $1-24$

Øresland, V. (1983). Abundance, breeding and temporal size distribution of the chaetognath Sagitta setosa in the Kattegat. J. Plankton Res. 5: 425-439

$\varnothing$ resland, V (1985). Temporal size and maturity-stage distribution of Sagitta elegans and occurrence of other chaetognath species in Gullmarsfjorden, Sweden. Sarsia 70: $95-101$

Pingree, R. D. (1980). Physical oceanography of the Celtic Sea and English Channel. In: Banner, F. T., Collins, M. B. Massie, K. S. (ed.) Elsevier Oceanography Series Vol. 24B. The north-west European shelf seas: the sea bed and the sea in motion. II. Physical and chemical oceanography and physical resources. Elsevier, Amsterdam, p. 415-465

Russell, F. S. (1931). The vertical distribution of marine macroplankton. X. Notes on the behaviour of Sagitta in the Plymouth area. J. mar. biol. Ass. U. K. 17: 391-407

Russell, F. S. (1932). On the biology of Sagitta. II. The breeding and growth of Sagitta setosa J. Müller in the Plymouth area, 1930-31, with a comparison with that of Sagitta elegans Verrill. J. mar. biol. Ass. U. K. 18: 147-160

Russell, F. S. (1933). On the biology of Sagitta. III. A further observation on the growth and breeding of Sagitta setosa in the Plymouth area. J. mar. biol. A.ss. U.K. 18: 555-558

Russell, F. S. (1935). On the value of certain plankton animals as indicators of water movements in the English Channel and North Sea. J. mar. biol. Ass. U. K. 20: 309-332

Russell, F. S. (1939). Hydrographical and biological conditions in the North Sea as indicated by plankton organisms J. Cons. perm. int. Explor. Mer 14: 171-192

Southward A. J. (1962). The distribution of some plankton animals in the English Channel and approaches. II. J. mar biol. Ass. U. K. 42: 275-375

Southward, A. J. (1970). Improved methods of sampling post- 
larval young fish and macroplankton. J. mar. biol. Ass. U. K. 50: 689-712

Southward, A. J. (1980). The western English Channel - an inconstant ecosystem? Nature, Lond. 185: 361-366

Southward, A.J. (1984). Fluctuations in the 'indicator' chaetognaths Sagitta elegans and Sagitta setosa in the western Channel. Oceanologica Acta 7. 229-239
Southward, A. J., Barret, R. L. (1983). Observations on the vertical distribution of zooplankton, including post-larval teleosts, off Plymouth in the presence of a thermocline and a chlorophyll-dense layer J. Plankton Res. 5: 599-618

Zo, Z. (1973). Breeding and growth of the chaetognath Sagitta elegans in Bedford Basin. Limnol. Oceanogr. 18: 750-756

This paper was submitted to the editor; it was accepted for printing on November 29, 1985 